\title{
Mineralization characteristics and genesis of rare earth elements enrichment in marine phosphorites in China
}

\author{
JING-HONG YANG ${ }^{1}$, SHAO-YONG JIANG ${ }^{2}$, BI ZHU ${ }^{3}$, \\ DAO-HUI PI ${ }^{2}$, HUI-MIN SU ${ }^{2}$ \\ ${ }^{1}$ Nanjing University, Dept. of Earth Sciences and \\ Engineering, Nanjing, China (yangjh@nju.edu.cn) \\ ${ }^{2}$ China University of Geosciences, School of Earth \\ Resources, Wuhan 430074, China . \\ ${ }^{3}$ Hohai University, School of Earth Sciences and \\ Engineering, Nanjing 210098, China
}

Rare earth elements (REE) deposits occur primarily in four geologic environments: carbonatites, alkaline igneous systems, ion-adsorption clay deposits, and monazite-xenotime-bearing placer deposits. Light rare earth elements (LREE) resources are mainly from carbonatites (e.g. Bayan Obo, China; Mountain Pass, USA) and placer deposits, while the ion-adsorption clays are the leading source of heavy rare earth elements (HREE, e.g. Jiangxi, South China). Due to the high abundance of sedimentary marine phosphorite ores and the commonly high REE concentrations in these ores, the phosphorite deposits have attracted great attention as one of the potential new rare earth resource.

There are widespread occurrences of marine phosphorite deposits in China, and some of these deposits show high abundance of REE in particular the HREE. One of the typical example is the Zhijin phosphorite deposit in Guizhou Province, SW China. In this deposit, the total phosphorite ore reaches up to $3390 \mathrm{Mt} @ 17.2 \mathrm{wt} \% \mathrm{P}_{2} \mathrm{O}_{5}$, and the total $\mathrm{RE}_{2} \mathrm{O}_{3}$ resource has been estimated to be 3.5 $\mathrm{Mt} @ 0.104$ wt $\% \mathrm{RE}_{2} \mathrm{O}_{3}$. In particular, the HREE resource accounts for $1.24 \mathrm{Mt}$. The REE abundance in this deposit ranks 1 st for all the phosphorite deposits in China.

The second important REE resource of this type in China comes from the metamorphosed phosphorite bearing strata in the Qinling-Dabei orogenic belt in central China, where not only the phosphorite ores itself can contain up to $0.1 \mathrm{wt} \% \mathrm{RE}_{2} \mathrm{O}_{3}$, but also the leco-granulites and schists next to the phosphorite ore layers can contain independent HREE (Y) mineralization, and the ore minerals include gadolinite and fergusonite. A detailed geologic, petrographic, mineralogic and geochemical study indicate a significant role of hydrothermal fluid activity during the enrichment of REE in these sedimentary and metamorphic phosphorite ores and phosphorous bearing strata in China. 